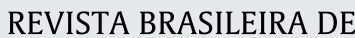

\section{A new species of Stenoptilia Hübner (Lepidoptera: Pterophoridae) associated with Neobartsia peruviana (Orobanchaceae) in the Andes of northern Chile}

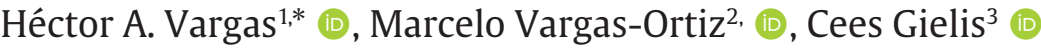 \\ ${ }^{1}$ Universidad de Tarapacá, Facultad de Ciencias Agronómicas, Departamento de Recursos Ambientales, Casilla 6-D, Arica, Chile \\ ${ }^{2}$ Universidad de Concepción, Departamento de Zoología, Facultad de Ciencias Naturales y Oceanográficas, Programa de Doctorado en \\ Sistemática y Biodiversidad, Casilla 160-C, Concepción, Chile \\ ${ }^{3}$ Naturalis Biodiversity Centre, P.O. Box 9517, 2300 RA Leiden, The Netherlands \\ urn:lsid:zoobank.org:pub:DAA2A5CF-5F56-445E-B3BC-67F282ADC81C
}

\section{A R T I C L E I N F O}

\section{Article history:}

Received 20 December 2019

Accepted 12 March 2020

Available online 15 May 2020

Associate Editor: Lucas Kaminski

\section{Keywords:}

Neotropical

Plume moths

Stenoptilia suprema Meyrick, 1926

Stenoptilia tenuis (Felder \& Rogenhofer,

1875)

\begin{abstract}
A B S T R A C T
The plume moth genus Stenoptilia Hübner, [1825] (Lepidoptera: Pterophoridae) is recorded for the first time from Chile. Adults of Stenoptilia socoromaensis Vargas \& Gielis sp. nov. from the northernmost part of the Chilean Andes are described and illustrated. The larvae of $S$. socoromaensis feed on buds, flowers and unripe fruits of the hemiparasitic plant Neobartsia peruviana (Walp.) Uribe-Convers \& Tank (Orobanchaceae). Pairwise distances of a DNA barcode sequence of $S$. socoromaensis with congeneric species ranged from 9.1 to $12.6 \%$ (K2P).
\end{abstract}

The first description of a plume moth (Lepidoptera: Pterophoridae) from Chile was published by Blanchard (1852). More than one hundred years passed until the first taxonomic revision of the Chilean fauna of Pterophoridae was available (Gielis, 1991), after which additional species have been discovered (Gielis, 2006, 2011a, 2012, 2013; Vargas, 2010). Currently, 46 plume moth species have been recorded in Chile, 22 of which appear to be endemics (Gielis, 1991, 2006, 2011a, 2012, 2013; Vargas, 2010). However, more species could still be discovered, because sampling for plume moths has been scarce in some parts of the country. This is the case of the Andes of the northernmost part of Chile, where only two species have been recorded (Vargas, 2010; Espinoza-Donoso et al., 2018), even though its arid environments harbor a relatively high diversity of native plants (Gatica-Castro et al., 2015).

Stenoptilia Hübner [1825] (Lepidoptera: Pterophoridae) is a widespread plume moth genus. Gielis (2003) listed 91 species worldwide and several others have been described thereafter (Gielis, 2008, 2011b, 2012, 2014;

\footnotetext{
* Corresponding author.

E-mail: havargas@uta.cl; lepvargas@gmail.com (H.A. Vargas).
}

Gielis and Mano, 2013; Ustjuzhanin et al., 2017). This genus is particularly diverse in the Palearctic, with more than 60 described species (Gielis, 2003). In contrast, only eight species of Stenoptilia have been recorded from the Neotropics (Gielis, 2006, 2012, 2014). Representatives of the genus were unknown from Chile until now. However, an undescribed species was recently discovered in a high elevation environment in the northernmost part of the country. Accordingly, the aim of this study is to describe the adult stage of the first species of Stenoptilia from Chile.

\section{Material and methods}

Collecting, rearing and morphological study

The study site is located near Socoroma village ( $18^{\circ} 16^{\prime} 45^{\prime \prime} S$; $69^{\circ} 35^{\prime} 22^{\prime \prime} W$ ), Parinacota Province, at about $3300 \mathrm{~m}$ elevation in the Andes of northern Chile. It has a tropical xeric climate with seasonal rains between December and March (Luebert and Pliscoff, 2006) and a seasonal vegetation cover with higher levels shortly after 
the rains (Muñoz and Bonacic, 2006). Larvae were collected on the hemiparasitic plant Neobartsia peruviana (Walp.) Uribe-Convers \& Tank (Orobanchaceae) in May 2017. They were feeding on buds, flowers and unripe fruits. The collected larvae were placed in plastic vials with pieces of the plant and paper towel at the bottom and brought to the laboratory. The vials were cleaned periodically and fresh leaves, flowers and unripe fruits were provided until the larvae finished feeding. Vials were observed regularly after pupation. One pupa was kept in ethanol 95\% until DNA extraction. The adults obtained were mounted, their abdomens were removed, cleared in hot $\mathrm{KOH} 10 \%$ for a few minutes, stained with Eosin Y and Chlorazol black and slide-mounted with Euparal. Images were captured with Sony CyberShot DSC-HX200V and Micropublisher 3.3 RTV-QImaging digital cameras attached to a Leica M125 stereomicroscope and an Olympus BX51 optical microscope, respectively.

\section{DNA extraction and phylogenetic analysis}

Genomic DNA was extracted from one pupa following the procedures described in Huanca-Mamani et al. (2015). Genomic DNA was sent to Macrogen Inc. (Seoul, South Korea) for purification, PCR amplification and sequencing of the DNA barcode fragment of the cytochrome oxidase subunit 1 (sensu Hebert et al., 2003a, 2003b) with the primers LCO-1490 and HCO-2198 (Folmer et al., 1994). Amplification procedures follow the PCR program described in Escobar-Suárez et al. (2017). Sequences of 658 base pair (bp) lengths of additional species of Stenoptilia and one sequence of Stenoptilodes taprobanes(Felder \& Rogenhofer, 1875) (Table 1) were downloaded from BOLD Systems (Ratnasingham and Hebert, 2007). The sequences were aligned with ClustalW in the software MEGA7 (Kumar et al., 2016). No presence of stop codons or gaps was detected. To evaluate the interspecific evolutionary distance proposed for DNA barcode (Hebert et al., 2003a, 2003b), genetic distance was assessed using the Kimura-2-parameter (K2P) model. The presence of phylogenetic signal was assessed with a substitution saturation analysis using the Xia test (Xia et al., 2003) in the Dambe 7.2.1 program (Xia, 2018). Because different evolutionary rates may occur along the marker used (e.g. Pentinsaari et al., 2016), the phylogenetic tree was inferred using a Bayesian Markov-chain Monte Carlo (BMCMC) framework with a general likelihood-based mixture model of gene sequence evolution (Pagel and Meade, 2004) using the BayesPhylogenies 1.1 software (University of Reading, 2019a). The MCMC analysis was run using 300,000,000 iterations, sampling every 10,000 trees, removing the first $15 \%$ as burn-in. Finally, the consensus phylogenetic tree was visualized in BayesTrees 1.3 (University of Reading, 2019b).

\section{Abbreviations of institutional collections}

MNNC: Museo Nacional de Historia Natural de Santiago, Santiago, Chile IDEA: Colección Entomológica de la Universidad de Tarapacá, Arica, Chile

\section{Results}

Stenoptilia socoromaensis Vargas \& Gielis sp. nov.

urn:Isid:zoobank.org:act:7BFF1CE4-CB9F-437A-BD76-7F6F6AF7A1FC (Figs. 1-3)

Type material. Holotype, male, preserved pinned and dried: CHILE. Chile, Parinacota, Socoroma, emerged June 2017, H.A. Vargas coll.,

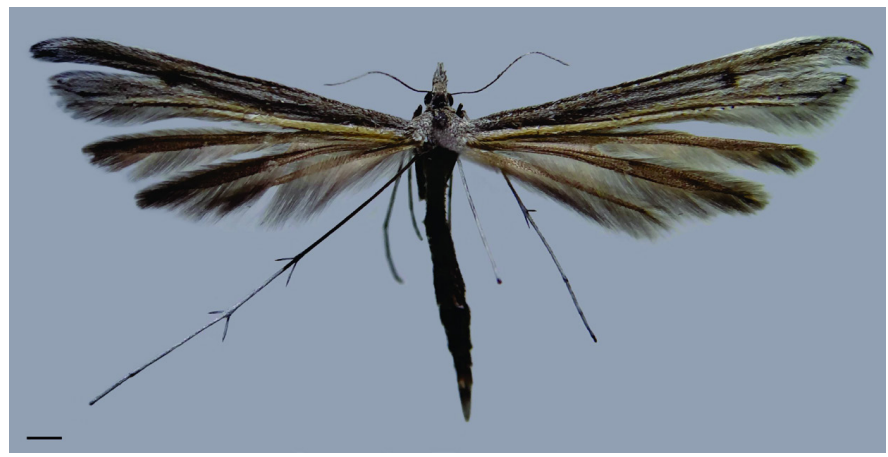

Figure 1 Male holotype of Stenoptilia socoromaensis Vargas \& Gielis sp. nov. in dorsal view. Scale bar: $1 \mathrm{~mm}$.

Table 1

Sequences used in the molecular analysis.

\begin{tabular}{|c|c|c|c|}
\hline Species & BOLD accession & GenBank accession & Country \\
\hline Stenoptilia socoromaensis Vargas \& Gielis sp. nov. & & MN847778 & Chile \\
\hline Stenoptilia annadactyla Sutter, 1988 & FBLMS219-09 & GU706533 & Germany \\
\hline Stenoptilia bigoti Gibeaux, 1986 & PHLAB792-10 & HQ968800 & Italy \\
\hline Stenoptilia bipunctidactyla (Scopoli, 1763) & DEEUR1018-16 & & Austria \\
\hline Stenoptilia coprodactyla (Stainton, 1851) & ABOLA790-15 & & Austria \\
\hline Stenoptilia graphodactyla (Treitschke, 1833) & LASTS572-14 & & Austria \\
\hline Stenoptilia islandica(Staudinger, 1857) & LEFIA025-10 & HМ396375 & Finland \\
\hline Stenoptilia Iutescens (Herrich-Schäffer, 1855) & PHLAB763-10 & HQ968774 & Italy \\
\hline Stenoptilia mariaeluisae Bigot \& Picard, 2002 & PHLAH601-12 & KP253705 & Austria \\
\hline Stenoptilia mengeli Fernald, 1898 & GRAFW298-11 & KU373285 & Greenland \\
\hline Stenoptilia mimula Gibeaux, 1985 & PHLSA348-11 & JN277260 & Spain \\
\hline Stenoptilia nolckeni(Tengstrom, 1870) & LEFII194-11 & KT782438 & Finland \\
\hline Stenoptilia pelidnodactyla (Stein, 1837) & LEFIG350-10 & HM876027 & Finland \\
\hline Stenoptilia pneumonanthes (Büttner, 1880) & LEEUA261-11 & JN277213 & Denmark \\
\hline Stenoptilia plagiodactyla (Stainton, 1851) & PHLAH575-12 & KР253229 & Austria \\
\hline Stenoptilia pterodactyla (Linnaeus, 1761) & FBLMS218-09 & HМ901993 & Germany \\
\hline Stenoptilia stigmatodactyla (Zeller, 1852) & LEATC462-13 & & Austria \\
\hline Stenoptilia veronicae Karvonen, 1932 & LEFIA1376-10 & GU828689 & Finland \\
\hline Stenoptilia zophodactyla (Duponchel, 1838) & ANICG159-10 & HQ922425 & Australia \\
\hline Stenoptilodes taprobanes (Felder \& Rogenhofer, 1875) & BCMI450-11 & & Israel \\
\hline
\end{tabular}


ex-larva Neobartsia peruviana, collected May 2017, genitalia slide HAV-1319 (MNNC).

Paratypes: Adults preserved pinned and dried. One male, genitalia slide HAV-1074, two females, genitalia slides HAV-1073, HAV-1303; same data as holotype (MNNC). Two males, genitalia slides HAV-1302, HAV-1305, one female, genitalia slide HAV-1306, same data as holotype (IDEA).

\section{Diagnosis}

Stenoptilia socoromaensis is recognized by the morphology of the genitalia. The male has a short, narrow uncus whose apex surpasses the excavation of the tegumen, juxta somewhat semicircular with thickened dorsal margin and phallus with narrow cornutus in the vesica. The female has a cone-like antrum with slightly sinuous sides and broadly excavated postero-ventral margin.

\section{Description}

Male (Figs. 1 and 2). Forewing length: 11.3-11.8 $\mathrm{mm}(\mathrm{n}=4)$.

Head. Vertex and frons mostly brownish grey, laterally flanked by a creamy white stripe with a few brownish yellow scales anteriorly. Antenna filiform, shortly ciliated, mostly creamy white, brownish grey scales scattered. Labial palp; first segment mostly creamy white, brownish grey dorso-apically; second segment mostly brownish grey, creamy white ventrally; third segment mostly brownish grey, creamy white dorso-apically.

Thorax. Dorsally mostly brownish grey, a slightly differentiated creamy white transverse stripe in the posterior margin of mesothorax; metathorax brownish yellow, laterally mostly brownish yellow. Foreleg mostly creamy white with brownish grey scales scattered, excepting brownish yellow coxa. Midleg and hind leg mostly creamy white with brownish grey scales scattered, one and two pairs of tibial spurs, respectively. Forewing dorsal surface mostly brownish grey with creamy white and dark brown scales scattered; a dark brown circular spot before the base of cleft; a narrow longitudinal dark brown stripe on the basal two thirds of the first lobe; a somewhat broad longitudinal brownish yellow stripe on anal margin, well differentiated basally, gradually obscured towards the base of the second lobe; fringe with brownish grey, creamy white and dark brown scales, one small dark brown blotch on anal margin of first lobe, two on distal margin of second lobe; ventral surface mostly brownish grey with creamy white scales on distal portion of the two lobes. Hindwing dorsal surface brownish grey; fringe brownish grey; ventral surface mostly brownish grey, first lobe with abundant creamy white scales scattered, third lobe mostly creamy white; two longitudinal rows of reddish brown venous scales, the anterior row longer, without scales in the medial third.
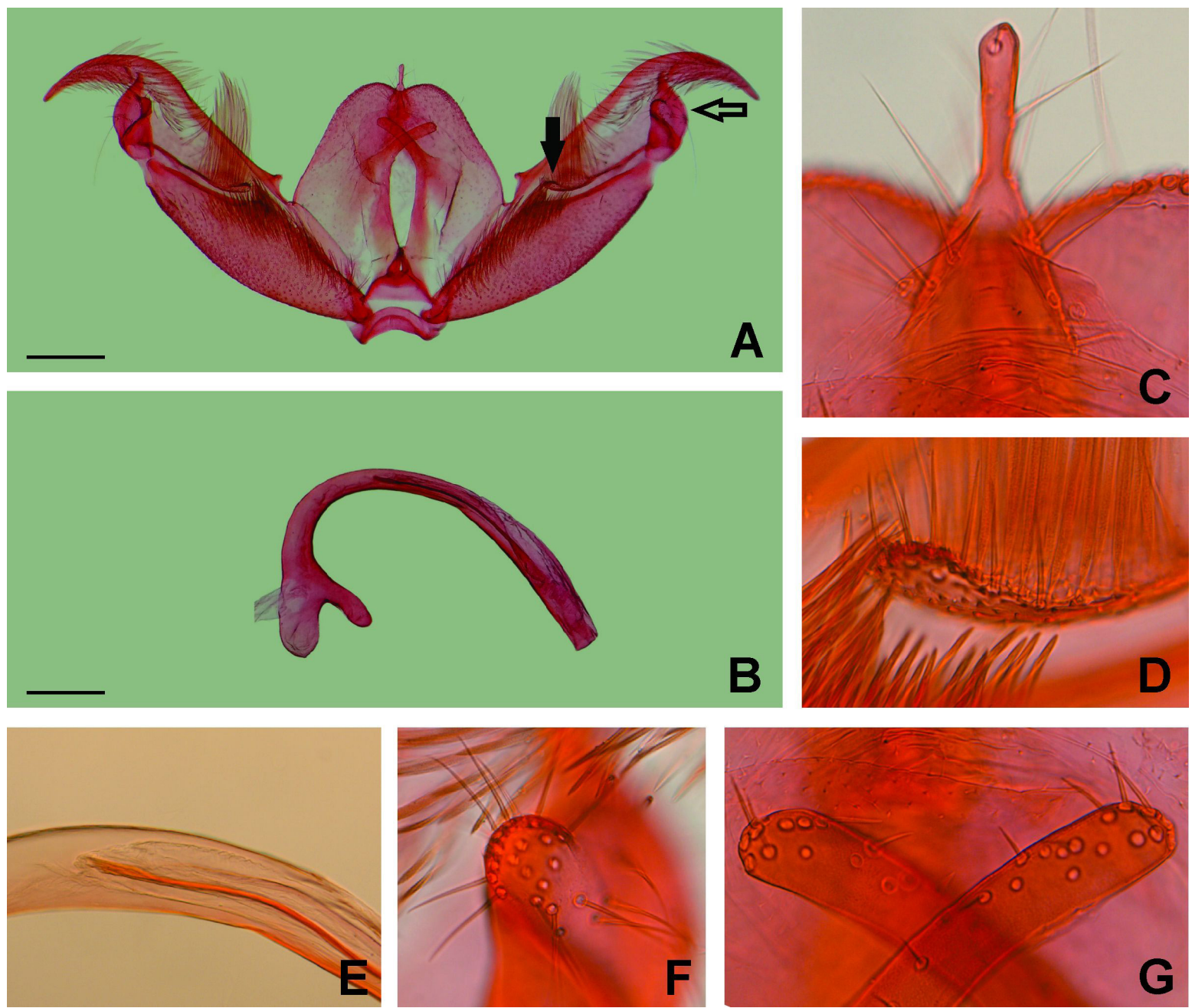

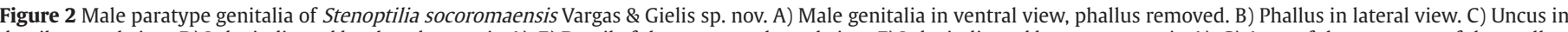

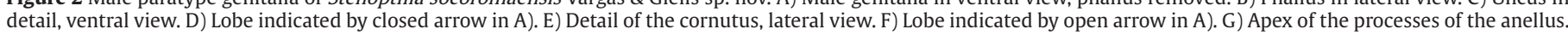
Scale bars: $0.2 \mathrm{~mm}$. 
Abdomen. Mostly yellowish brown dorsally, narrow longitudinal creamy white stripe on lateral margins of terga I-VIII, slightly differentiated creamy white transversal stripe on distal margin of terga III-VII, two dark brown spots on distal margin of terga II-VII. Mostly brownish grey latero-ventrally, slightly differentiated creamy white longitudinal stripes, creamy white and dark brown scales scattered.

Male genitalia (Fig. 2)

Tegumen bilobed, excavated sub-terminally, posterior portion folded. Uncus triangular basally, cylindrical distally, a few short setae on the two parts, apex of uncus surpasses the excavation of the tegumen. Saccus narrow, slightly thickened ventrally. Juxta somewhat semicircular, ventral margin straight, dorsal margin thickened. Anellus slightly sclerotized, lateral margin slightly differentiated; anellus arm finger-like, about 1.5 times length of uncus, a few setae at apex. Valvae symmetrical; costa straight basally, down curved distally; long hair-like setae from a small lobe near base of costa; cucullus as a downward-curved projection with narrow, rounded apex; sacculus bilobed, basal lobe triangular, short hair-like setae near proximal margin, ventral margin convex, distal lobe semicircular, about a third of basal lobe length, a small blister-like lobe on distal half bearing a few setae. Phallus strongly curved, coecum small, cylindrical, width about half that of base of phallus, vesica with narrow cornutus, length about half that of phallus.

Female. Similar to male in coloration and size.

Female genitalia (Fig. 3)

Papillae anales slightly sclerotized, long hair-like setae mostly apically, short hair-like microtrichia basally. Posterior apophyses about four times the length of papillae anales. Anterior apophyses
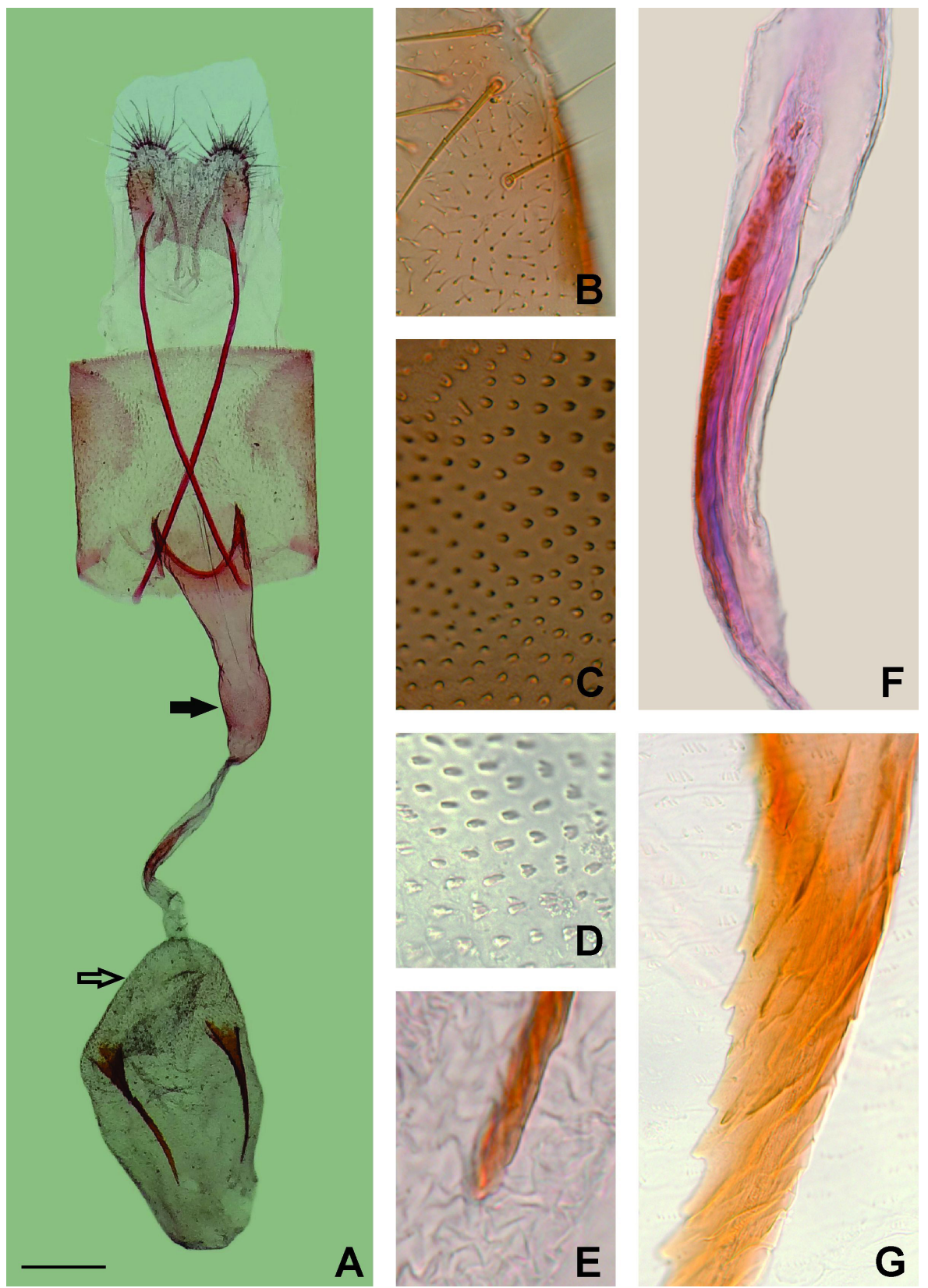

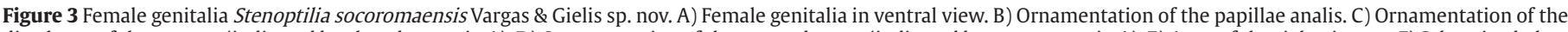

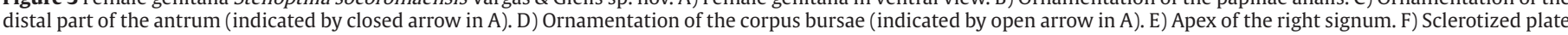
of ductus bursae. G) Basal part of the right signum. Scale bar: $0.2 \mathrm{~mm}$. 
absent. Antrum cone-like, slightly sinuous laterally, length about two thirds that of posterior apophyses, tubercle-like ornamentation, postero-ventral margin broadly excavated, a sclerotized lateral tab on each side of ostium. Ductus bursae membranous, slightly shorter than antrum, narrow sclerite longitudinally on central third. Corpus bursae membranous, sub-spherical, slightly elongated, finely scobinate, two horn-like signa with mesal margin serrated.

Geographic distribution (Fig. 4)

Stenoptilia socoromaensis is known from the type locality in the neighborhood of Socoroma, Parinacota Province, northern Chile.

Host plant (Fig. 4)

The larvae of $S$. socoromaensis feed on buds, flowers and unripe fruits of Neobartsia peruviana(Walp.) Uribe-Convers \& Tank (Orobanchaceae).
Neobartsia is a South American genus of hemiparasitic plants mainly associated with the Andes highlands (Uribe-Convers and Tank, 2016).

\section{Etymology}

The specific epithet is derived from Socoroma, the type locality of S. socoromaensis.

DNA barcodes and phylogeny (Fig. 5)

Pairwise distances of the DNA barcode sequence of $S$. socoromaensis (GenBank accession MN847778) with congeneric species ranged from 9.1 to $12.6 \%$ (K2P). The lowest interspecific divergence was between Stenoptilia mengeli Fernald, 1898 and Stenoptilia islandicus
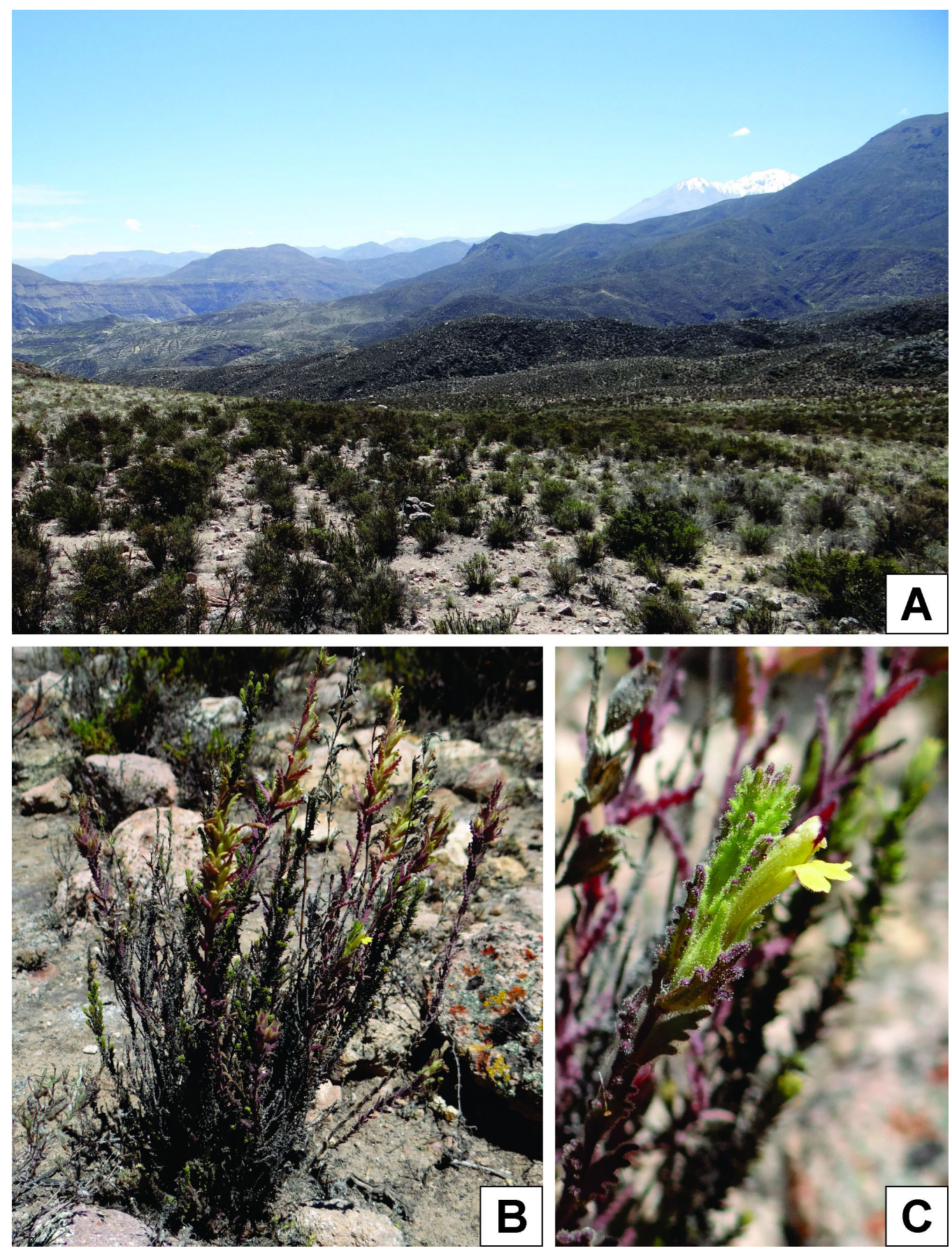

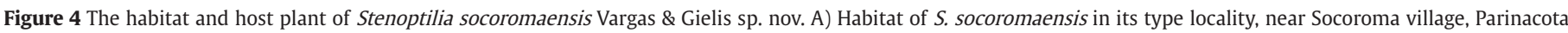
Province, at about $3400 \mathrm{~m}$ elevation on the Andes of northern Chile. B) The host plant Neobartsia peruviana at the type locality. C) Flower in detail. 


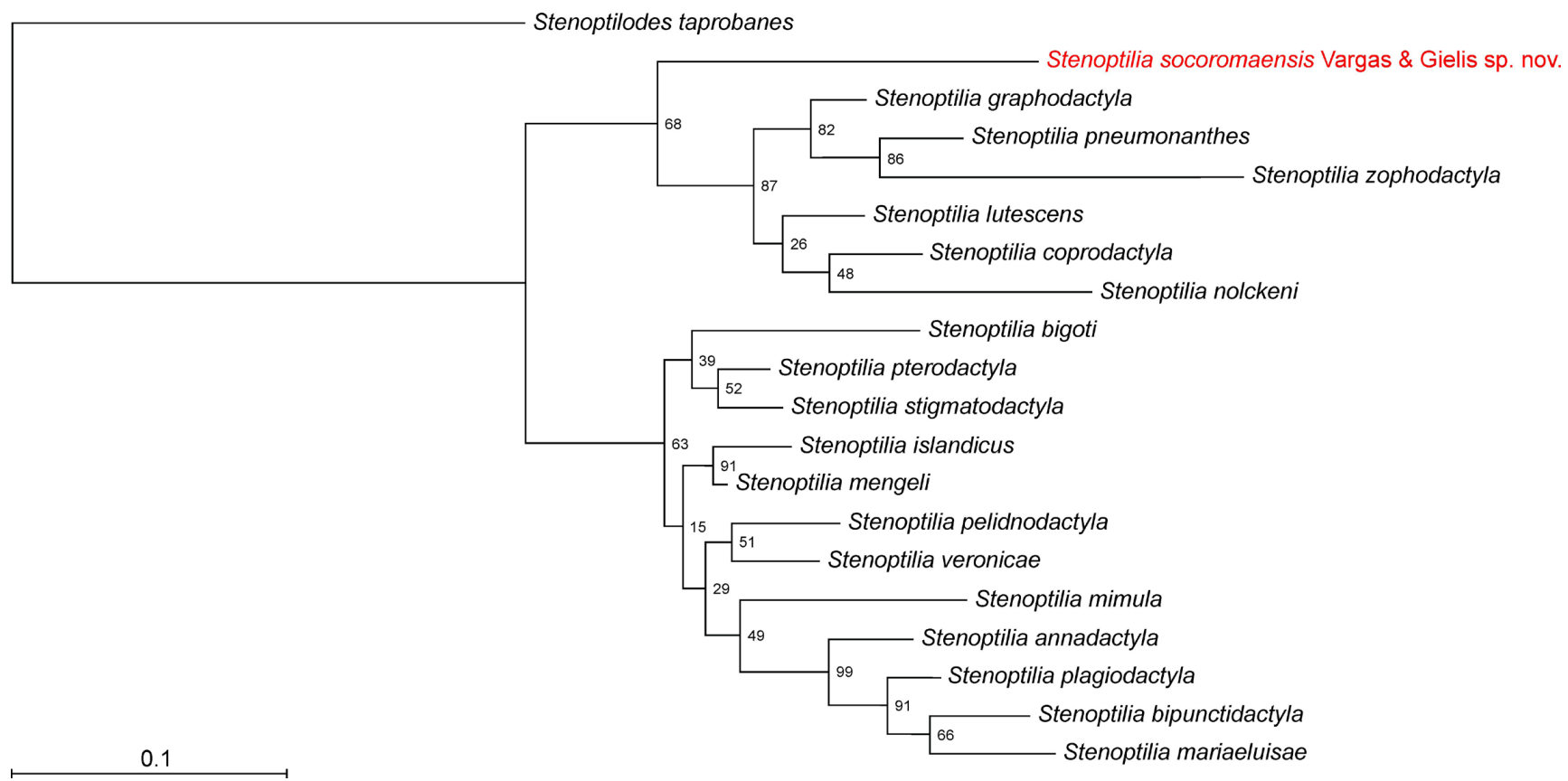

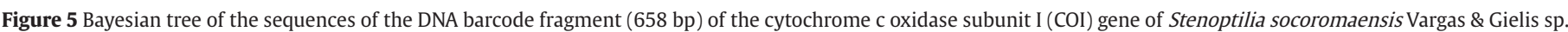
nov. (highlighted in red) and congeneric species. Numbers indicate node support (posterior probability) of branches.

(Staudinger, 1857). The BMCMC analysis separated the sequences of the species of Stenoptilia into two groups; the sequence of $S$. socoromaensis was placed at the base of one of them.

\section{Discussion}

Stenoptilia socoromaensis is the first species of the genus described from Chile. The morphology suggests that $S$. socoromaensis belongs to the group of Stenoptilia tenuis (Felder \& Rogenhofer, 1875), from Colombia, Ecuador and Peru, and Stenoptilia suprema Meyrick, 1926, from Bolivia, Colombia, Ecuador and Peru (Gielis, 2006). However, S. socoromaensis shows more black scales in the second forewing lobe. In the male genitalia of this species the valva has a longer and slender apical part; the uncus reaches well over the tegumen, in contrast to the other two species; and the anellus arms are longer than in S. tenuis and slightly longer than in S. suprema. In the female genitalia of S. socoromaensis the ostium bursae is wider than in the other two species; the antrum in S. suprema is longer and more slender, while in S. tenuis the antrum is slightly more slender; and the signum is much longer and more pronounced in S. socoromaensis than in the other two species.

Only two species of Stenoptilia from the Neotropics have a long, narrow cornutus in the vesica like $S$. socoromaensis: the widespread Stenoptilia zophodactyla (Duponchel, 1838), originally described from France and also found in the New World (Gielis, 2006), and the Neotropical S. neblina Gielis, 1995, only known from Venezuela (Gielis, 1995). However, these two species can be accurately separated from $S$. socoromaensis based on the fringe pattern of the first forewing lobe, which has a single dot near the anal angle in S. socoromaensis, and a double dot in both other species; and in the morphology of the male genitalia, S. zophodactyla and S. neblina have lateral pointed extensions near the top of the tegumen, which are absent in $S$. socoromaensis. In addition, the juxta is wider in $S$. zophodactyla and $S$. neblina than in $S$. socoromaensis. In the female genitalia, the sclerite of the ductus bursae is relatively small in $S$. socoromaensis, being restricted to its central third, while the length of the sclerite is about a half of the ductus bursae in $S$. zophodactyla and comprises almost the complete length of the ductus bursae in $S$. neblina.
Although surveys for plume moths are generally focused on the adult stage, searching for their immature stages on plants provides interesting additional information about their natural history, enabling further research involving both the plume moth and its host plants (e.g. Matthews, 2006; Vargas et al., 2018). Host plant records are known for 23 species of Stenoptilia, many of which feed on plants of only one or two families; the most polyphagous species is the Palearctic Stenoptilia bipunctidactyla (Scopoli, 1763), whose larvae feed on plants of at least nine families (Matthews and Lott, 2005 ). Larvae of $S$. socoromaensis were found only on $N$. peruviana at the study site, although they were also searched for on native plants of Asteraceae, Fabaceae, Malvaceae, Solanaceae, Verbenaceae and Vivianiaceae without success, suggesting a narrow host range. Accordingly, larvae of $S$. socoromaensis should be searched for throughout the geographic range of $N$. peruviana, in the highlands of the Andes of southern Peru and northern Chile, as a first step to characterize adequately the geographic range of this plume moth. The discovery of $S$. socoromaensis represents the first record of herbivory by Lepidoptera on $N$. peruviana. As the vulnerable status was recently proposed for this plant in its narrow Chilean range (Gatica-Castro et al., 2015) and the host range of $S$. socoromaensis appears to be narrow, further studies are needed to understand better the interaction between this plume moth and its host plant.

The clustering of the DNA barcode sequence of $S$. socoromaensis with congenerics agrees with the morphological evidence in recognizing this species as a member of Stenoptilia. Morphological and molecular analysis of a greater number of species of the genus, especially the Neotropical representatives, would certainly be needed to assess the evolutionary relationships of $S$. socoromaensis. The recent discovery of many plume moths in the Neotropical Region (e.g. Landry et al., 2004; Gielis, 2006, 2011a, 2012, 2013, 2014; Matthews et al., 2012. 2019), including $S$. socoromaensis and some other representatives of Stenoptilia, suggests that surveys in undersampled habitats could be extremely useful to characterize better the taxonomic diversity of the genus Stenoptilia and the complete family Pterophoridae in the Neotropics. 


\section{Acknowledgements}

We thank Wilson Huanca-Mamani for the use of facilities for DNA extraction, Sebastián Espinoza-Donoso for editing the figures and Lafayette Eaton for checking the English. Suggestions of three anonymous reviewers substantially improved the first version of the manuscript.

\section{Conflicts of interest}

The authors declare no conflicts of interest.

\section{Compliance with ethical standards}

The specimens were collected in accordance to national legislation of Chile. Type material is deposited in public scientific collections.

\section{Author contribution statement}

HAV conducted fieldwork and dissections. CG compared morphological structures with congeneric species. MVO conducted the laboratory procedures and molecular analysis. All authors conceived the research and wrote a part of the manuscript. All authors approved the final version of the article.

\section{References}

Blanchard, E., 1852. Fauna chilena: insectos, orden VI, lepidópteros. In: Gay, C., (Ed.), Historia Física y Política de Chile. Vol. 7. Paris, pp. 1-112.

Escobar-Suárez, S., Huanca-Mamani, W., Vargas, H. A., 2017. Genetic divergence of a newly documented population of the cecidogenous micromoth Eugnosta azapaensis Vargas \& Moreira (Lepidoptera: Tortricidae) in the Atacama Desert of northern Chile. Rev. Bras. Entomol. 61 (3), 266-270. http://dx.doi.org/10.1016/j.rbe.2017.05.004.

Espinoza-Donoso, S., Parra, L. E., González-Espinoza, C., Vargas-Ortiz, M., Vargas, H. A., 2018. Morphology of the immature stages and notes on the natural history of the little-known plume moth Stenoptilodes juanfernandicus Gielis (Lepidoptera: pterophoridae). Zootaxa 4462 (3), 415-425. http://dx.doi.org/10.11646/zootaxa.4462.3.7.

Folmer, O., Black, M., Hoeh, W., Lutz, R., Vrijenhoek, R., 1994. DNA primers for amplification of mitochondrial cytochrome c oxidase subunit I from diverse metazoan invertebrates. Mol. Mar. Biol. Biotechnol. 3, 294-299.

Gatica-Castro, A., Marticorena, A., Rojas, G., Arancio, G., Squeo, F. A., 2015. Estado de conservación de la flora nativa de las regiones de Arica-Parinacota y de Tarapacá, Chile. Gayana Bot. 72 (2), 305-339. http://dx.doi.org/10.4067/S0717-66432015000200013.

Gielis, C., 1991. A taxonomic review of the Pterophoridae (Lepidoptera) from Argentina and Chile. Zool. Verh. Leiden 269, 1-164.

Gielis, C., 1995. Neotropical Pterophoridae 11: the genus Stenoptilia. Shilap Revta. Lepid. 23, 141-152.

Gielis, C., 2003. World Catalogue of Insects, 4: Pterophoroidea \& Alucitoidea. Apollo Books, Stenstrup. http://dx.doi.org/10.1002/ mmnd.20030500211.

Gielis, C., 2006. Review of the Neotropical species of the family Pterophoridae, part I: Ochyroticinae, Deuterocopinae, Pterophorinae (Platyptiliini, Exelastini, Oxyptilini) (Lepidoptera). Zool. Med. Leiden 80-2, 1-290.

Gielis, C., 2008. Ten new species of Afrotropical Pterophoridae (Lepidoptera). Zool. Med. Leiden 82, 43-57.
Gielis, C., 2011a. Review of the neotropical species of the family Pterophoridae, part II: Pterophorinae (Oidaematophorini, Pterophorini) (Lepidoptera). Zool. Med. Leiden 85, 1-409.

Gielis, C., 2011b. Notes on some African Pterophoridae, with description of new species (Lepidoptera). Bol. SEA 49, 33-63.

Gielis, C., 2012. Review of the Neotropical species of the family Pterophoridae, part 3: additions from Chile, Ecuador and Paraguay (Lepidoptera). Bol. SEA 51, 105-124.

Gielis, C., 2013. Review of the Neotropical species of the family Pterophoridae, part 4: additions from Argentina, Bolivia, Chile and Uruguay (Lepidotera). Bol. SEA 53, 95-109.

Gielis, C., 2014. Review of the Neotropical species of the family Pterophoridae, part 5: additions from Peru, Ecuador, Colombia, Venezuela and the Guyanas (Lepidoptera). Bol. SEA 55, 67-91.

Gielis, C., Mano, T., 2013. Additions to the Pterophoridae fauna of Japan (Lepidoptera). Tinea 22, 149-155.

Hebert, P. D. N., Cywinska, A., Ball, S. L., deWaard, J. R., 2003a. Biological identification through DNA barcode. Proc. Biol. Sci. 270 (1512), 313-321. http://dx.doi.org/10.1098/rspb.2002.2218.

Hebert, P. D. N., Ratnasingham, S., DeWaard, J. R., 2003b. Barcoding animal life: cytochrome c oxidase subunit 1 divergences among closely related species. Proc. Biol. Sci. 270 (Suppl.1), S96-S99. http:// doi.org/10.1098/rsbl.2003.0025.

Huanca-Mamani, W., Rivera-Cabello, D., Maita-Maita, J., 2015. A simple, fast, and inexpensive CTAB-PVP-Silica based method for genomic DNA isolation from single, small insect larvae and pupae. Genet. Mol. Res. 14(3), 7990-8000. http://dx.doi.org/10.4238/2015.July.17.8.

Kumar, S., Stecher, G., Tamura, K., 2016. MEGA7: molecular evolutionary genetics analysis version 7.0 for bigger datasets. Mol. Biol. Evol. 33 (7), 1870-1874. http://dx.doi.org/10.1093/molbev/msw054.

Landry, B., Roque-Abelo, L., Matthews, D. L., 2004. Supplemental additions to the Pterophoridae of the Galapagos Islands (Ecuador), with description of a new species of Adaina. Mitt. Schweiz. Ent. Ges. 77, 289-310. https://doi.org/10.5169/seals-402873.

Luebert, F., Pliscoff, P., 2006. Sinopsis Bioclimática y Vegetacional de Chile. Editorial Universitaria, Santiago.

Matthews, D. L., 2006. Larvae and Pupae of Nearctic Pterophoridae: A Synopsis of Life Histories, Morphology, and Taxonomy (Lepidoptera: Pterophoroidea). Unpublished PhD Dissertation, University of Florida, Gainesville.

Matthews, D. L., Lott, T. A., 2005. Larval host plants of the Pterophoridae (Lepidoptera: pterophoridae). Mem. Am. Entomol. Inst. 76, 1-324.

Matthews, D. L., Miller, J. Y., Simon, M. J., Goss, G., 2012. Observations of plume moths on North Andros Island, Bahamas, and notes on new records and species previously recorded from the Bahamas (Lepidoptera: pterophoridae). Insecta Mundi 0236, 1-12.

Matthews, D. L., Miller, J. Y., Simon, M., Goss, G., 2019. Additions to the plume moth fauna of The Bahamas. Insecta Mundi 0708, 1-35.

Muñoz, A. E., Bonacic, C., 2006. Variación estacional de la flora y vegetación en la precordillera andina de la comuna de Putre (I Región de Tarapacá, Chile) durante el período 2002-2003. Gayana Bot. 63 (1), 75-92. http://dx.doi.org/10.4067/S0717-66432006000100003.

Pagel, M., Meade, A., 2004. A phylogenetic mixture model for detecting pattern-heterogeneity in gene sequence or character-state data. Syst. Biol. 53 (4), 571-581. http://dx.doi.org/10.1080/10635150490468675.

Pentinsaari, M., Salmela, H., Mutanen, M., Roslin, T., 2016. Molecular evolution of a widely-adopted taxonomic marker (COI) across the animal tree of life. Sci. Rep. 6 (1), 35275. http://dx.doi.org/10.1038/ srep35275.

Ratnasingham, S., Hebert, P. D. N., 2007. BOLD: the barcode of life data system. Mol. Ecol. Notes 7 (3), 355-367. http://dx.doi.org/10.1111/ j.1471-8286.2007.01678.x. 
University of Reading, 2019a. BayesPhylogenies 1.1 Software. Available in: http://www.evolution.rdg.ac.uk/SoftwareMain.html (accessed 20 December 2019).

University of Reading, 2019b. BayesTrees 1.3. Available in: http://www. evolution.rdg.ac.uk/SoftwareMain.html (accessed 20 December 2019).

Uribe-Convers, S., Tank, D. C., 2016. Phylogenetic revision of the genus Bartsia (Orobanchaceae): disjunct distributions correlate to independent lineages. Syst. Bot. 41 (3), 672-684. http://dx.doi. org/10.1600/036364416X692299.

Ustjuzhanin, P., Rekelj, J., Kovtunovich, V., Ustjuzhanina, A., 2017. Pterophoridae (Lepidoptera) fauna of the Republic of Tuva. Zootaxa 4319 (2), 317-328. http://dx.doi.org/10.11646/Zootaxa.4319.2.3.
Vargas, H. A., 2010. A new species of LioptilodesZimmerman (Lepidoptera, Pterophoridae) from northern Chile. Rev. Bras. Entomol. 54 (3), 428-430. http://dx.doi.org/10.1590/S0085-56262010000300011.

Vargas, H. A., Rasmann, S., Ramirez-Verdugo, P., Villagra, C. A., 2018. Lioptilodes friasi (Lepidoptera: Pterophoridae) niche breadth in the Chilean mediterranean matorral biome: trophic and altitudinal dimensions. Neotrop. Entomol. 47 (1),62-68. http://dx.doi.org/10.1007/ s13744-017-0514-2.

Xia, X., 2018. DAMBE7: new and improved tools for data analysis in molecular biology and evolution. Mol. Biol. Evol. 35 (6), 1550-1552. http://dx.doi.org/10.1093/molbev/msy073.

Xia, X., Xie, Z., Salemi, M., Chen, L., Wang, Y., 2003. An index of substitution saturation and its application. Mol. Phylogenet. Evol. 26 (1), 1-7. http://dx.doi.org/10.1016/S1055-7903(02)00326-3. 